\title{
Factors Affecting the Lactoferrin Concentration in Bovine Milk
}

\author{
J. B. Cheng, ${ }^{\star}$ J. Q. Wang, ${ }^{11}$ D. P. Bu, ${ }^{\star}$ G. L. Liu, ${ }^{\star}$ C. G. Zhang, ${ }^{*} †$ H. Y. Wei, ${ }^{*} \ddagger$ L. Y. Zhou, ${ }^{*} \ddagger$ and J. Z. Wang ${ }^{\star}$ \\ *State Key Laboratory of Animal Nutrition, Institute of Animal Science, Chinese Academy of Agricultural Sciences, Beijing, 100094, P. R. China \\ †College of Animal Science and Technology of Yangzhou University, Yangzhou, 225009, P. R. China \\ $\ddagger$ Ministry of Agricultural Milk and Dairy Inspection and Supervision Center (Beijing), Beijing, 100094, P. R. China
}

\begin{abstract}
Lactoferrin (LF) concentrations in the milk with different levels of the somatic cell count score were examined using an ELISA to determine whether milk LF concentration is influenced by parity of the cow, stage of lactation, and the somatic cell count. The study animals were 198 Chinese Holstein cows randomly chosen from more than 1,600 cows in 4 dairy farms in the Beijing area. The cows had shown no sign of mastitis for 2 mo. Daily milk production was recorded, and milk samples were taken from individual cow samples. The LF concentration varied between 31.78 and $485.63 \mu \mathrm{g} / \mathrm{mL}$ in milk from normal animals. Lactoferrin was significantly associated with stage of lactation $(r=0.557)$ and daily milk production $(\mathrm{r}=-0.472)$. Nevertheless, there was no significant relationship with parity. Moreover, milk LF concentration tended to be correlated with the somatic cell count score $(r=0.375)$. This finding suggests that milk LF may be helpful as an indicator for intramammary infection in dairy cows.
\end{abstract}

Key words: bovine milk, lactoferrin, parity, somatic cell count score

\section{INTRODUCTION}

Lactoferrin $(\mathbf{L F})$ is an iron-binding glycoprotein that is synthesized by specific granules in PMNL (Baggiolini et al., 1970) and glandular epithelial cells (Masson et al., 1966). Lactoferrin is present in milk and on mucosal surfaces (Rerter and Oram, 1967). In milk, LF plays a key role in the defense mechanisms of the mammary gland of lactating animals. Bacteria require iron for growth, and LF can inhibit bacteria by chelating iron under certain conditions (Weinberg, 1978). In addition to its iron-binding function, LF may directly kill certain bacterial strains (Bellamy et al., 1992) or may weaken bacterial resistance by adhesion to the surface of bacteria (Arnold et al., 1977).

Received September 14, 2007.

Accepted December 4, 2007.

${ }^{1}$ Corresponding author: wang-jia-qi@263.net
A number of studies described factors that affect the relative LF concentration in milk. Harmon et al. (1975) reported that the LF concentration of milk was significantly associated with SCC, levels of BSA, stage of lactation, and milk production. Still, LF had a negative relationship with milk production. Tsuji et al. (1990) reported that the LF content of multiparous cows was 2 to 3 times higher than that of primiparous cows. The highest LF content in colostrum was observed in second lactation. After the third lactation, no differences in LF content were observed. Hagiwara et al. (2003) reported that the concentration of milk LF was significantly related to the age of cows but not to the stage of lactation; however, because those samples were from different mammary gland quarters and the sample number was relatively small, further studies are needed to validate the conclusions.

Previous studies have not clearly established the relationship between the milk LF concentration and the potential factors affecting that concentration. The purpose of this study was to quantify LF concentrations in normal milk and to examine the factors affecting milk LF, such as the lactation stage, daily milk production, parity, and SCC in the milk.

\section{MATERIALS AND METHODS}

\section{Cows}

Chinese Holstein cows $(\mathrm{n}=198)$ were randomly chosen from more than 1,600 animals across 4 dairy farms in the greater Beijing area. The animals had shown no signs of mastitis (by checking the presence of redness, swelling, hardness, and pain in the udder, or the presence of clots in the milk) for 2 mo before selection. All the cows were housed the same, and the diets were mixed and fed as TMR 3 times daily. Parity of lactating cows was $2.02 \pm 1.30$, and the average daily milk production was $23.23 \pm 6.57 \mathrm{~kg}$.

\section{Milk Samples}

Duplicate milk samples from each cow were collected on the sampling day (a.m. and p.m.). One set of milk 
samples $(50 \mathrm{~mL})$ from each milking obtained according to milk yield, preserved with bronopol-B2, was analyzed for fat, protein, lactose, total solid, and SCC using nearmidinfrared procedures with a MilkoScan Minor machine (MilkoScan 4000, Foss Electric, Hillerød, Denmark). Another set of milk samples $(30 \mathrm{~mL})$ from individual cows was obtained from the 2 milkings by milk yield and was centrifuged at $10,000 \times \mathrm{g}$ for $15 \mathrm{~min}$ at $4^{\circ} \mathrm{C}$ to remove the fat (Legend Mach 1.6/R, Sorvall, Germany). The skimmed milk was collected and frozen at $-80^{\circ} \mathrm{C}$ for subsequent analysis.

\section{Quantitative Determination of LF in Milk by Sandwich ELISA}

Quantitative determination of LF in the skim milk samples was performed using a commercial ELISA, the Bovine Lactoferrin ELISA Quantification Kit (Bethyl Laboratories, Montgomery, TX). The final absorbance of the samples was measured at $450 \mathrm{~nm}$, using an ELISA plate-reader (Infinite F200; Tecan, Männedorf, Switzerland). The procedures were performed according to the instructions of the manufacturer. The milk samples were diluted 1:2,000, and a standard curve was generated for each set of samples. Assay precision was defined by determining intraassay and interassay variation. Intraassay variation was determined by 10 successive analyses of a milk sample at 3 different dilutions $(1: 1,000 ; 1: 2,000 ; 1: 3,000)$. Interassay variation was evaluated with the same milk sample in 10 different runs. The intraassay and interassay coefficients of variation were 8.5 and $9.8 \%$, respectively.

\section{Stage of Lactation and Daily Milk Production}

The lactation stage was classified by the number of days from parturition, and daily milk production was classified as shown in Table 1.

\section{scs}

The SCC in milk was determined with a Fossomatic Cell Counter (Integrated Milk Testing, Fossomatic 5000, Foss Electric). The DHI program has adopted a SCC scoring system (Harmon, 1994) that divides the SCC of composite milk into 10 categories from 0 to 9 . The SCC data were converted into SCS $\left(\mathrm{SCS}=\log _{2}\right.$ $[\mathrm{SCC} / 100,000]+3)$ by the number of somatic cells, as shown in Table 1. The SCC in the milk was used to assess whether the cow had developed subclinical mastitis. A SCS value of $\leq 3$ (SCC of $<141,000$ cells $/ \mathrm{mL}$ ) was normal, and 122 cows of the 198 cows had a SCS $\leq 3$. The relationship between the SCS and milk LF concentration was analyzed using all 198 cows.
Table 1. Mean \pm SD of lactoferrin (LF) concentrations in the milk from normal lactating cows (1-way ANOVA)

\begin{tabular}{lccc}
\hline & $\begin{array}{c}\text { Number } \\
\text { of samples } \\
(\mathrm{n}=122)\end{array}$ & $\begin{array}{c}\text { Milk LF } \\
\text { concentration } \\
(\log )\end{array}$ & $\begin{array}{c}\text { Significance } \\
(P)\end{array}$ \\
\hline Parmal milk & & & \\
1 & 63 & $2.015 \pm 0.214$ & $=0.537$ \\
2 & 19 & $1.939 \pm 0.236$ & \\
3 & 21 & $2.042 \pm 0.231$ & \\
4 & 8 & $2.057 \pm 0.128$ & \\
$\geq 5$ & 11 & $2.077 \pm 0.297$ & \\
Stage of lactation ${ }^{1}$ & & & \\
Peak period & 49 & $1.898 \pm 0.121^{\mathrm{c}}$ & $<0.001$ \\
Middle period & 45 & $2.033 \pm 0.280^{\mathrm{b}}$ & \\
Late period & 28 & $2.195 \pm 0.203^{\mathrm{a}}$ & \\
Daily milk production ${ }^{2}$ & & & \\
Y1 & 36 & $2.183 \pm 0.248^{\mathrm{a}}$ & $<0.001$ \\
Y2 & 34 & $1.992 \pm 0.228^{\mathrm{b}}$ & \\
Y3 & 33 & $1.928 \pm 0.163^{\mathrm{b}}$ & \\
Y4 & 19 & $1.894 \pm 0.175^{\mathrm{b}}$ & \\
SCS & & & \\
SCS 0 & & & \\
SCS 1 & 12 & $1.914 \pm 0.137$ & $=0.084$ \\
SCS 2 & 20 & $2.022 \pm 0.174$ & \\
SCS 3 & 50 & $1.980 \pm 0.191$ & \\
\hline
\end{tabular}

${ }^{\mathrm{a}-\mathrm{c}}$ Superscripts indicate differences in the means with $P$-value as mentioned in column for significance $(P<0.05$ indicates significance; $P<0.01$ indicates high significance).

${ }^{1}$ Stage of lactation was classified as follows: peak period $=21$ to $100 \mathrm{~d}$ from parturition; middle period $=101$ to $200 \mathrm{~d}$ from parturition; late period $=201 \mathrm{~d}$ from parturition to the end of lactation.

${ }^{2}$ Daily milk production was classified as follows: Y1 $<20 \mathrm{~kg} ; 20 \mathrm{~kg}$ $\leq \mathrm{Y} 2<25 \mathrm{~kg} ; 25 \mathrm{~kg} \leq \mathrm{Y} 3<30 \mathrm{~kg} ; \mathrm{Y} 4 \geq 30 \mathrm{~kg}$.

${ }^{3} \mathrm{SCS}$ was classified by the number of somatic cells in milk as follows: $0 \leq$ SCS $0<18,000 ; 18,000 \leq$ SCS $1<35,000 ; 35,000 \leq$ SCS $2<71,000 ; 71,000 \leq$ SCS $3<141,000 ; 141,000 \leq$ SCS $4<283,000$; $283,000 \leq$ SCS $5<566,000 ; 566,000 \leq \operatorname{SCS} 6<1,131,000 ; 1,131,000$ $\leq \operatorname{SCS} 7<2,263,000 ; 2,263,000 \leq \operatorname{SCS} 8<4,526,000 ; 4,526,000 \leq \mathrm{SCS}$ 9 .

\section{Statistical Analysis}

The measured LF concentration $(\mu \mathrm{g} / \mathrm{mL})$ data were transformed into logarithmic form, and the distribution of the milk LF concentration (log) was assessed by a $\chi^{2}$ test for goodness of fit. The correlation coefficients among classified factors and other indices were analyzed by Spearman's correlation coefficient. Homogeneities of variance were analyzed by Bartlett's test in groups classified by the stage of lactation, daily milk production, parity, and SCS. Using the results of Bartlett's test, the differences in milk LF concentration (log) among groups were analyzed by 1-way ANOVA. Finally, a factorial ANOVA was conducted, with $P<0.05$ considered significant and those $<0.01$ considered highly significant.

\section{RESULTS}

\section{Milk LF Concentrations in Normal Lactating Cows}

The milk LF concentration in normal lactating cows $(61.6 \%)$ was $115.4 \pm 67.4$ and ranged from 31.8 to 485.6 


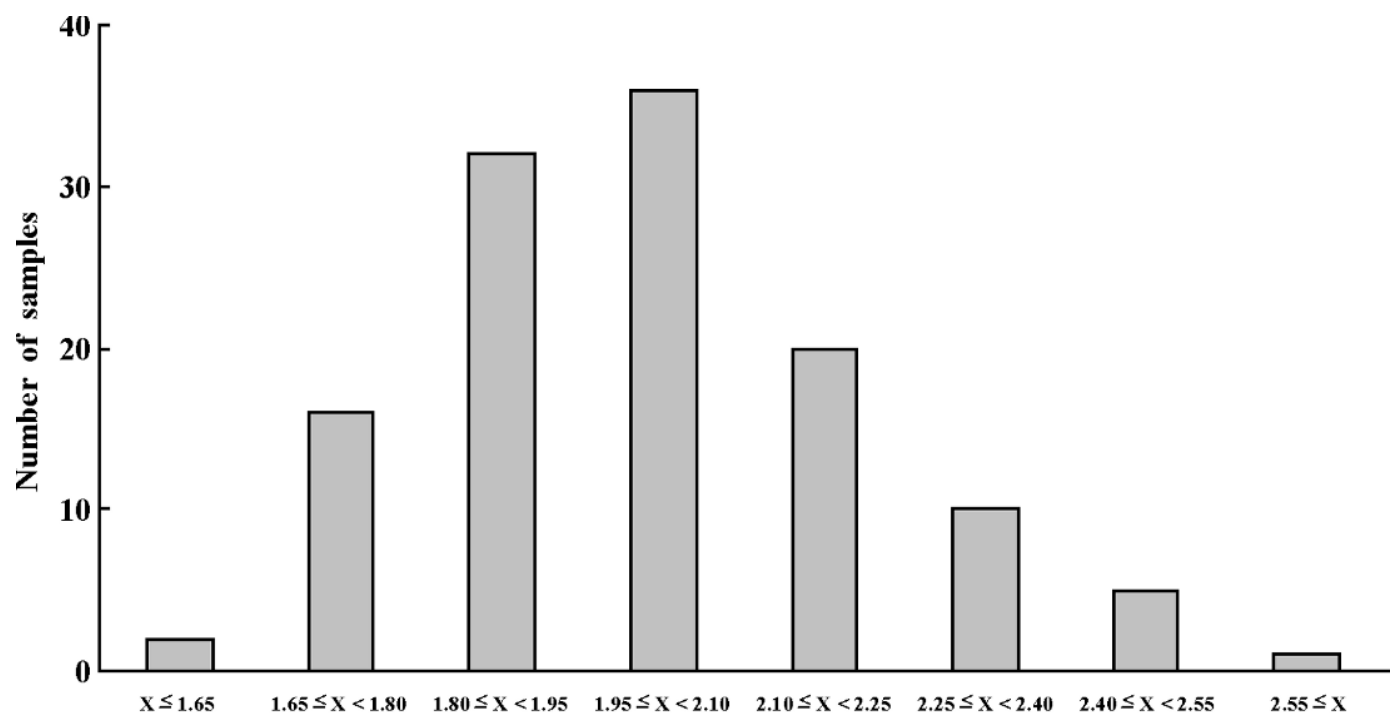

Milk LF concentration (log)

Figure 1. Distribution of lactoferrin (LF) concentration (log) in 122 normal milk samples.

$\mu \mathrm{g} / \mathrm{mL}(\mathrm{n}=122)$. The milk LF concentration in normal lactating cows showed a normal distribution after logarithmic transformation ( $\chi^{2}$ test for goodness of fit, $P>$ 0.05 ; Figure 1). The $95 \%$ confidence range (mean $\pm \mathrm{SD}$ ) for the milk LF concentration in normal lactating cows ranged between 37.95 and $271.07 \mu \mathrm{g} / \mathrm{mL}$, with a mean concentration of $101.43 \pm 45.48 \mu \mathrm{g} / \mathrm{mL}$.

\section{Correlation Between LF and Parity, Stage} of Lactation, Daily Milk Production, Fat, Protein, Lactose, TS, and SCC (log) in the Normal Milk

Lactoferrin was correlated with the stage of lactation $(\mathrm{r}=0.557 ; P<0.001)$, daily milk production $(\mathrm{r}=-0.472$; $P<0.001)$, milk protein $(\mathrm{r}=0.482 ; P<0.001)$, and lactose $(\mathrm{r}=-0.183 ; P=0.049)$. In contrast, parity, SCC (log), fat content of the milk, and TS were not correlated.

\section{Milk LF Concentration in the Normal Milk}

The LF concentration of milk did not differ significantly by parity. Yet, the concentration of LF tended to be higher for parities 3,4 , and $\geq 5$ than for parities 1 and 2 (Table 1). Table 1 shows the milk LF concentration (log) in normal lactating cows classified according to the lactation stage. The relationship between the milk LF concentration and lactation stage is in Figure 2 . The milk LF concentration increased $(P<0.01)$ as the lactation stage increased, with the highest mean milk LF concentration (log) in cows in the late lactation period and the lowest in cows in the peak lactation period (Table 1). The negative relationship of LF and daily milk production is in Figure 3. The milk LF concentration decreased $(P<0.01)$ as the daily milk production increased (Table 1). The milk LF concentration was

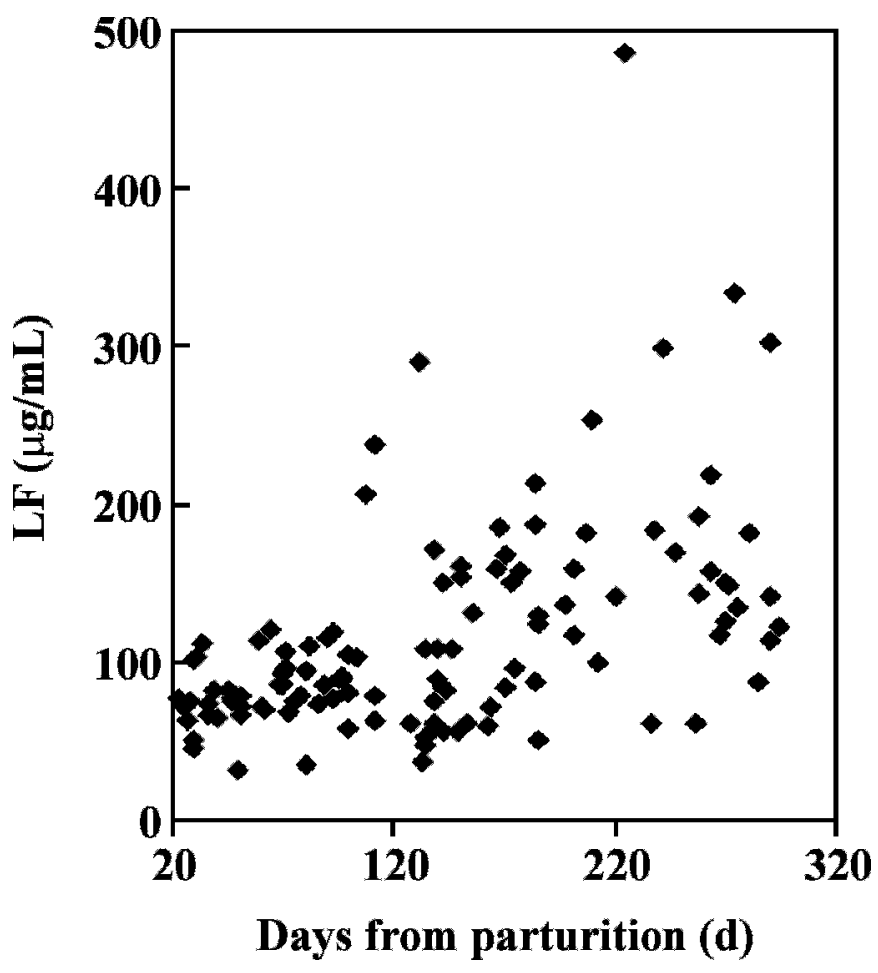

Figure 2. Relationship between the stage of lactation and milk lactoferrin $(\mathrm{LF})$ concentration $(\mu \mathrm{g} / \mathrm{mL})$. 


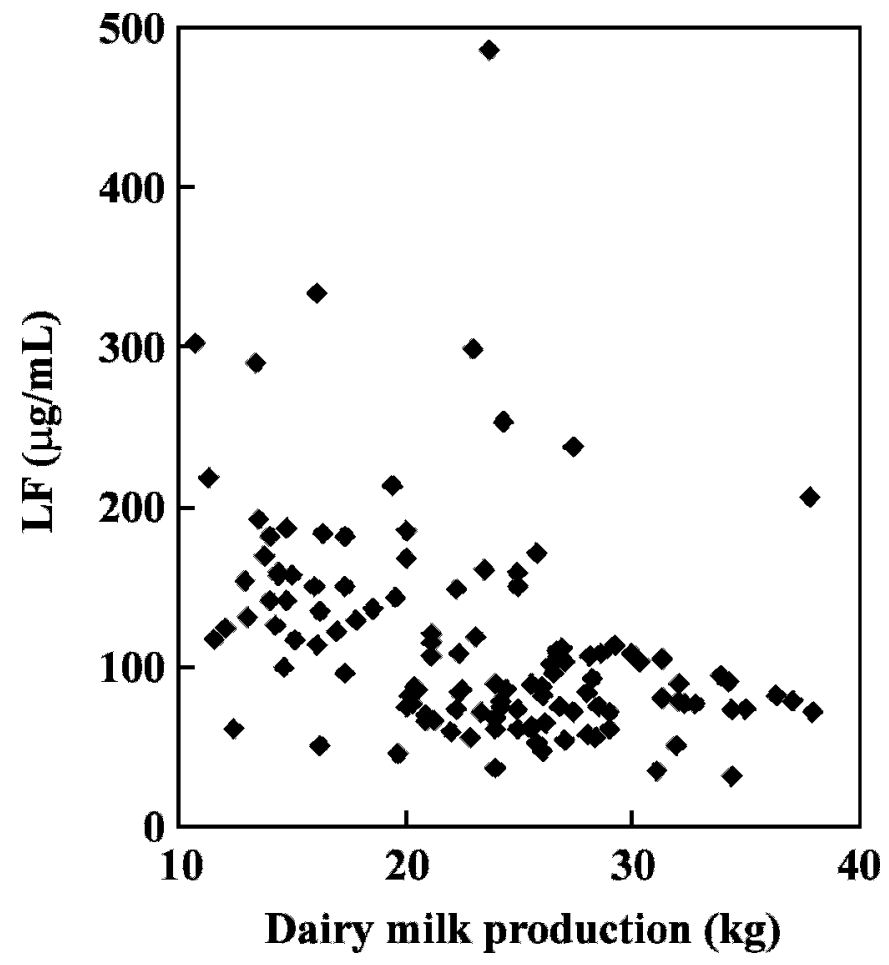

Figure 3. Relationship between the daily milk production and milk lactoferrin $(\mathrm{LF})$ concentration $(\mu \mathrm{g} / \mathrm{mL})$.

not significantly different in the SCS 0 , SCS 1 , SCS 2 , and SCS 3 groups (Table 1).

\section{Correlation of Various Factors to the Milk LF Concentration in the Normal Milk}

According to the factorial analysis presented in Table 2 , the stage of lactation and daily milk production significantly influenced the milk LF concentration $(P<$
0.01). Milk LF concentration was significantly affected by the interactions of those factors (Table 2).

\section{Relationship Between Milk LF Concentration and SCS in Milk Samples}

The relationship between milk LF concentration and SCS in milk samples $(\mathrm{n}=198)$ is shown in Figure 4. The value of milk LF concentration in SCS $4(\mathrm{n}=34)$, SCS $5(\mathrm{n}=20)$, and SCS $6(\mathrm{n}=22)$ was $2.098 \pm 0.245$, $2.262 \pm 0.317$, and $2.276 \pm 0.303$, respectively. The milk LF concentrations in SCS 5 and SCS 6 samples were significantly higher than that in SCS $0, \operatorname{SCS} 1$, SCS 2, and SCS 3 groups but not different from SCS 4 samples. In addition, the milk LF concentration was correlated with the SCS ( $\mathrm{r}=0.375$, Spearman correlation test; $P$ $<0.001)$.

\section{DISCUSSION}

\section{Milk LF Concentrations in Normal Lactating Cows}

Lactoferrin has been quantified in milk using different techniques such as capillary electrophoresis (Riechel et al., 1998) and reversed-phase HPLC (Palman and Elgar, 2002). Several immunoassays have been developed for this purpose. A review of the different immunological techniques available to quantify LF concentration concluded that immunodiffusion techniques have inherently low sensitivity and have generally been superseded by the more sensitive ELISA techniques (Harvey and Enríco, 2005). In this study, we chose the Bovine Lactoferrin ELISA Quantification Kit from Bethyl Laboratories and found a milk LF level of 101.43 $\mu \mathrm{g} / \mathrm{mL}$ in normal bovine milk. Our results were similar to those of Hagiwara et al. (2003) and Chen and Mao

Table 2. The factorial analysis (factorial ANOVA) for the lactoferrin (LF) concentration in the milk from normal lactating cows

\begin{tabular}{lcccc}
\hline & Number of & & $\begin{array}{c}\text { Significance } \\
(P)\end{array}$ & Power \\
Item & samples & df & 0.095 & 0.585 \\
\hline Parity & 122 & 4 & $<0.001$ & 0.999 \\
Stage of lactation & & 2 & $<0.001$ & 0.991 \\
Daily milk production & & 3 & 0.157 & 0.444 \\
SCC & & 6 & 0.179 & 0.552 \\
Parity $\times$ stage of lactation & 9 & 0.012 & 0.915 \\
Parity $\times$ daily milk production & 9 & 0.001 & 0.979 \\
Parity $\times$ SCC & 5 & 0.018 & 0.828 \\
Stage of lactation $\times$ daily milk production & 5 & 0.003 & 0.938 \\
Stage of lactation $\times$ SCC & 7 & 0.775 & 0.226 \\
Daily milk production $\times$ SCC & 2 & 0.493 & 0.165 \\
Parity $\times$ stage of lactation $\times$ daily milk production & & 3 & 0.004 & 0.897 \\
Parity $\times$ stage of lactation $\times$ SCC & 2 & 0.803 & 0.083 \\
Parity $\times$ daily milk production $\times$ SCC & 3 & 0.023 & 0.740 \\
Stage of lactation $\times$ daily milk production $\times$ SCC & & & &
\end{tabular}




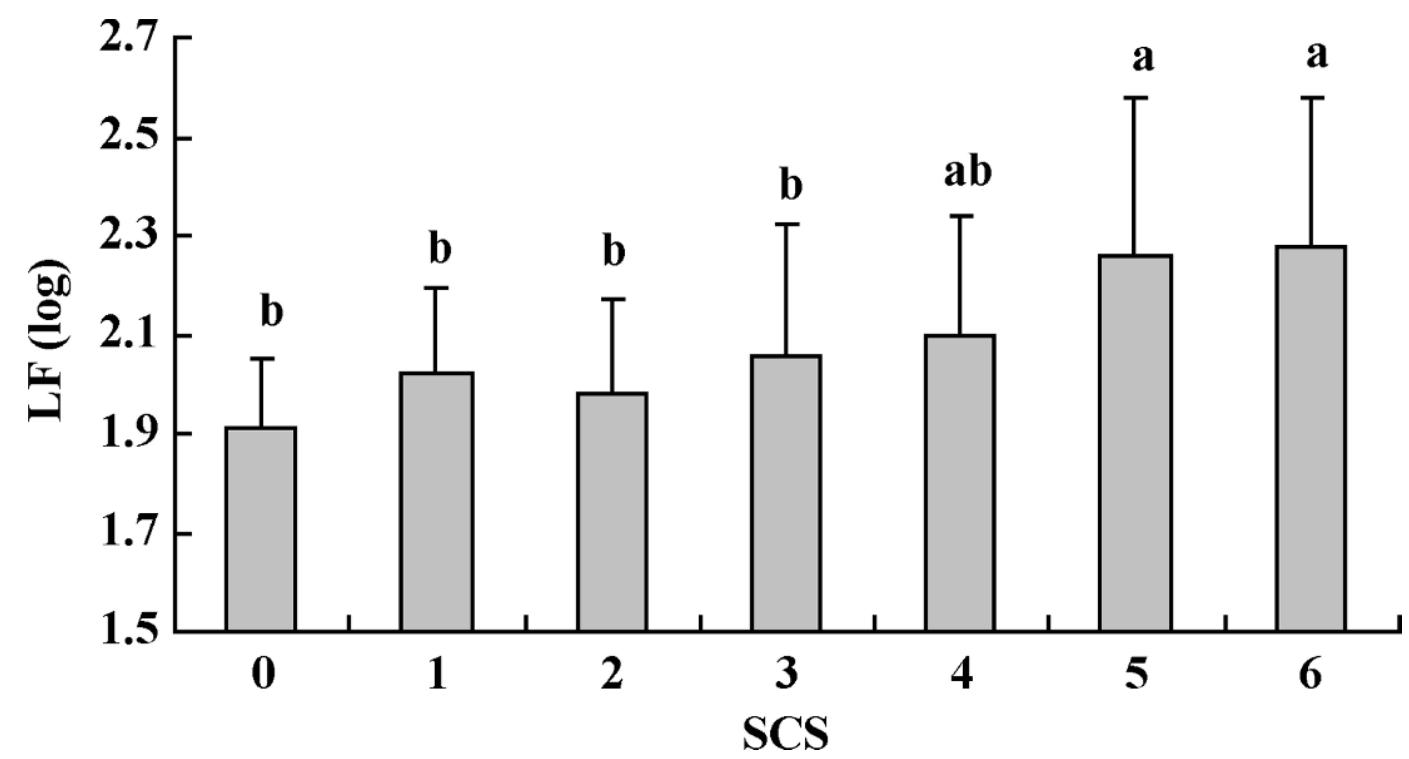

Figure 4. Relationship between the SCS and milk lactoferrin (LF) concentration (log) in 198 milk samples. ${ }^{\text {a,b }}$ Different letters indicate a significant difference.

(2004). Using immunodiffusion and competitive ELISA methods, they found LF concentrations of 169.06 and $176 \mu \mathrm{g} / \mathrm{mL}$ in raw bovine milk with $\mathrm{SCC}<100,000$ cells/ $\mathrm{mL}$, respectively. The differences may be due to number of samples, parity, health condition, and milk production of the cows. The 122 normal cows with no sign of mastitis for the 2 mo before this study had parity of $2.02 \pm 1.30$ and daily milk production of $23.23 \pm 6.57 \mathrm{~kg}$.

\section{Criteria for Determining Normal Cows}

The SCC in milk constitutes a good diagnostic tool that allows early detection of either subclinical or acute form of mastitis (Green et al., 2004) and is a valuable component of monitoring programs (Schukken at al., 2003). The SCC for normal milks was nearly always $<200,000$ cells $/ \mathrm{mL}$ (lower for first-lactation cows). An elevation is abnormal and indicated inflammation in the udder. Factors such as late lactation, old age, and environmental stress may cause slight elevations of SCC, but such increases are inconsequential when compared with the elevation that results from infection (Harmon, 1994). Yet, the distribution of SCC was highly skewed, with a majority of low values $(<100,000$ cells/ $\mathrm{mL}$ ) and a small proportion of very high values (up to several millions). On the other hand, most factors influence SCC in a multiplicative way. That is why SCC is usually transformed on a logarithm scale (Ali and Shook, 1980).

Cows with SCC $<200,000$ are not likely infected with major mastitis pathogens, but cows with $\mathrm{SCC}>300,000$ are probably infected. A 300,000-SCC threshold of infec- tion would be comparable to a SCS of 5 and above (Jones, 1998). In this study, a cow with a SCS value no more than 3 (SCC of $<141,000$ cells $/ \mathrm{mL}$ ) was considered normal, and 122 samples from cows in normal state $(61.6 \%)$ were used.

\section{Factors Affecting the Milk LF Concentration in Normal Milk}

In this study, the milk LF concentration was correlated to stage of lactation $(\mathrm{r}=0.557)$ and daily milk production $(\mathrm{r}=-0.472)$ but was not correlated to parity. These results agree with Harmon et al. (1975). But, Hagiwara et al. (2003) reported that the milk LF concentration $(\log )$ in normal 5 -yr-old lactating cows was lower than that in normal 2-yr-old and 3-yr-old lactating cows. These conflicting results might reflect differences in the sample size and criteria for selecting normal milk samples.

In our study, LF and lactose $(\mathrm{r}=-0.183)$ showed a negative relationship. This may be because that elevated SCC reduced synthetic activity of the mammary tissue. Korhonen and Kaartinen (1995) found that elevated SCC was usually associated with a decrease in lactose compared with milk with lower SCC. The milk LF concentration tended to increase in proportion to the increase in the SCS, which was similar to results by Hagiwara et al. (2003). The factorial ANOVA test results (Table 2) revealed the following descending order of influence on milk LF concentration: stage of lactation, daily milk production, parity by SCC, stage of lactation by SCC, and parity $\times$ stage of lactation $\times$ SCC 
interactions. Among these factors, stage of lactation and daily milk production contributed the most to the milk LF concentration. As we know, epithelial cells in the bovine mammary gland produce LF. Stage of lactation had a correlation to daily milk production ( $\mathrm{r}=$ -0.624 ), and the effects of lactation stage and daily milk production on the LF concentration in normal milk both reached a significant level. Therefore, many factors (including interactions between and among factors) may contribute to the change of LF concentration in the normal milk.

\section{Relationship Between Milk LF Concentration and SCS in Milk Samples}

Our result indicated that milk LF concentration tended to be high when SCS increased. Although there was no difference in the milk LF concentration in normal lactating cows when the SCS was no more than 3 , the milk LF concentration increased when the SCS exceeded 4 (Figure 4). In addition, the milk LF concentration was correlated with SCS $(\mathrm{r}=0.375)$. These results indicate that LF could be used as a complementary test to SCC and possibly a diagnostic test of subclinical mastitis in dairy cattle. Lindmark-Månsson et al. (2000) reported that elevated SCC was accompanied by decreasing milk yield and changes in milk composition. This may be due to the higher SCC in milk with higher levels of PMNL, which synthesize LF. Harmon and Newbould (1980) reported that LF concentration increases accompany the elevation of SCC and inflammation in an infected mammary gland, likely because of increased output by the mammary tissue and a minor contribution from PMNL, not simply a result of decreased milk production and hence a concentrating of the protein. Sordillo et al. (1987) reported that increased LF secretion was sustained for many days beyond the reclosure of epithelial tight junctions under certain pathological conditions, such as inflammation (mastitis).

Early detection of mastitis cows is important for most dairy farmers to reduce production losses and to enhance prospects of recovery. Indeed, using monthly SCC allows only the detection of $30 \%$ of clinical cases, because of duration of clinical mastitis and potentially different pathogens involved (Rupp and Boichard, 2003). Much effort has been expended to provide veterinarians and farmers with an efficient tool for mastitis detection. Many promising tests have been developed, such as measurements of milk conductivity, BSA, lactose, milk enzymes, and ATP. Among those tests, the predictive ability was highest for ATP, SCC, and Nacetyl- $\beta$-D-glucosaminidase (Emanuelson et al., 1987).
Valenti and Antonini (2005) reported that LF is a key element in the host innate defense system with its antimicrobial properties, which include iron sequestration, direct lytic activities, and the ability of the molecule to impair the binding of microbes to host cells. In addition, Harmon et al. (1976) reported that the milk LF concentration increased immediately when the udder had been infected.

\section{CONCLUSIONS}

This investigation of LF concentration in the milk from normal lactating cows showed that stage of lactation and daily milk production contributed the most to it, whereas parity showed no association. The LF concentration in milk had a relation to SCS; the correlation indicated that testing for the milk LF concentration may complement testing for SCS.

\section{ACKNOWLEDGMENTS}

This work was partially funded by grants from the Ministry of Science and Technology and Ministry of Agricultural of China (2006BAD12B08 and 2006DFB32160). We thank the staff of the State Key Laboratory of Animal Nutrition. We acknowledge the kind contributions of the personnel of the participating dairy farms.

\section{REFERENCES}

Ali, A. K. A., and G. E. Shook. 1980. An optimum transformation for somatic cell concentration in milk. J. Dairy Sci. 63:487-490.

Arnold, R. R., M. F. Cole, and J. R. McGhee. 1977. A bactericidal eject for human lactoferrin. Science 197:263-265.

Baggiolini, M., C. De Duve, P. L. Masson, and J. F. Heremans. 1970. Association of lactoferrin with specific granules in rabbit heterophil leukocytes. J. Exp. Med. 131:559-570.

Bellamy, W., M. Takase, K. Yamauchi, H. Wakabayashi, K. Kawase, and M. Tomita. 1992. Identification of the bactericidal domain of lactoferrin. Biochim. Biophys. Acta 1121:130-136.

Chen, P. W., and F. C. Mao. 2004. Detection of lactoferrin in bovine and goat milk by enzyme-linked immunosorbent assay. J. Food Drug. Anal. 12:133-139.

Emanuelson, U., T. Olasson, O. Holmberg, M. Hageltorn, T. Mattila, L. Nelson, and G. Åström. 1987. Comparison of some screening tests for detecting mastitis. J. Dairy Sci. 70:880-887.

Green, M. J., L. E. Green, Y. H. Schukken, A. J. Bradley, E. J. Peeler, H. W. Barkema, Y. de Haas, V. J. Collis, and G. F. Medley. 2004. Somatic cell count distributions during lactation predict clinical mastitis. J. Dairy Sci. 87:1256-1264.

Hagiwara, S., K. Kawai, A. Anri, and H. Nagahata. 2003. Lactoferrin concentrations in milk from normal and subclinical mastitic cows. J. Vet. Med. Sci. 65:319-323.

Harmon, R. J. 1994. Physiology of mastitis and factors affecting somatic cell counts. J. Dairy Sci. 77:2103-2112.

Harmon, R. J., and F. H. S. Newbould. 1980. Neutrophil leucocyte as a source of lactoferrin in bovine milk. Am. J. Vet. Res. 41:1603-1606.

Harmon, R. J., F. L. Schanbacher, L. C. Ferguson, and K. L. Smith. 1975. Concentration of lactoferrin in milk of normal lactating cows and changes occurring during mastitis. Am. J. Vet. Res. 36:1001-1007. 
Harmon, R. J., F. L. Schanbacher, L. C. Ferguson, and K. L. Smith. 1976. Changes in lactoferrin, immunoglobulin G, bovine serum albumin, and $\alpha$-lactalbumin during acute experimental and natural coliform mastitis in cows. Infect. Immun. 13:533-542.

Harvey, E. I., and L. F. Enríco. 2005. Determination of lactoferrin in bovine milk, colostrums and infant formulas by optical biosensor analysis. Int. Dairy J. 15:429-438.

Jones, G. M. 1998. Guidelines for Using the DHI Somatic Cell Count Program. Publication 404-228. Virginia Coop. Extension, Blacksburg, VA.

Korhonen, H., and L. Kaartinen. 1995. Changes in the composition of milk induced by mastitis. Pages 76-82 in The Bovine Udder and Mastitis. M. Sandholm, T. Honkanen-Buzalski, L. Kaartinen, and S. Pyörälä, ed. Univ. Helsinki, Helsinki, Finland.

Lindmark-Månsson, H., U. Svensson, M. Paulsson, G. Alden, B. Frank, and G. Johnsson. 2000. Influence of milk components, somatic cells and supplemental zinc on milk processability. Int. Dairy J. 10:423-433.

Masson, P. L., J. F. Heremans, J. J. Prignot, and G. Wauters. 1966. Immunohistochemical localization and bacteriostatic properties of an iron-binding protein from bronchial mucus. Thorax 21:538-544.

Palman, K. P., and D. F. Elgar. 2002. Detection and quantitation of lactoferrin in bovine whey samples by reversed-phase high- performance liquid chromatography on polystyrene-divinylbenzene. J. Chromatogr. A 947:307-311.

Rerter, B., and J. D. Oram. 1967. Bacterial inhibitors in milk and other biological fluids. Nature 216:328-330.

Riechel, P., T. Weiss, M. Weiss, R. Ulber, H. Buchholz, and T. Scheper. 1998. Determination of the minor whey protein bovine lactoferrin in cheese whey concentrates with capillary electrophoresis. J. Chromatogr. A 817:187-193.

Rupp, R., and D. Boichard. 2003. Genetics of resistance to mastitis in dairy cattle. Vet. Res. 34:671-688.

Schukken, Y. H., D. J. Wilson, F. Welcome, L. Garrison-Tikofsky, and R. N. Gonzalez. 2003. Monitoring udder health and milk quality using somatic cell counts. Vet. Res. 34:579-596.

Sordillo, L. M., S. C. Nickerson, R. M. Akers, and S. P. Oliver. 1987. Secretion composition during bovine mammary involution and the relationship with mastitis. Int. J. Biochem. 19:1165-1172.

Tsuji, S., Y. Hirata, F. Mukai, and S. Ohtagaki. 1990. Comparison of lactoferrin content in colostrum between different cattle breeds. J. Dairy Sci. 73:125-128.

Valenti, P., and G. Antonini. 2005. Lactoferrin: An important host defence against microbial and viral attack. Cell. Mol. Life Sci. 62:2576-2587.

Weinberg, E. D. 1978. Iron and infection. Microbiol. Rev. 42:45-66. 